\title{
Occurrence and genetic characterization of Staphylococcus aureus in milk samples of cattle with mastitis, and in the Veterinary Hospital personnel and dairy workers
}

\section{Ocorrência e caracterização genética de Staphylococcus aureus em amostras de leite de gado com mastite, na equipe de um Hospital Veterinário e em pessoas que trabalham com o gado leiteiro}

\author{
Lucianne LEIGUE ${ }^{1}$; Ayrton Rodrigo HILGERT²; Adriana FIORINI²; Marise Fonseca dos SANTOS²; \\ Eliane Cristina Gruzka VENDRUSCOLO ${ }^{2}$ \\ ${ }^{1}$ Universidade de São Paulo, Instituto de Ciências Biomédicas, Departamento de Microbiologia, São Paulo -SP, Brazil \\ ${ }^{2}$ Universidade Federal do Paraná, Departamento de Biociências, Palotina - PR, Brazil
}

\begin{abstract}
Staphylococcus aureus is one of the most common microorganisms responsible for high morbidity and mortality in humans and animals. Methicillin-resistant S. aureus are responsible for several outbreaks worldwide and therapeutic arsenal has become scarce. The present investigation verified the epidemiological profile of $S$. aureus strains isolated from the veterinary hospital staff, from dairy cattle workers and also from milk samples of dairy cattle presenting mastitis. Samples were characterized phenotypically by antibiogram, catalase, and coagulase tests, and also by Voges-Proskauer test. The isolated strains were characterized genotypically by specific Polymerase Chain Reaction and Amplified Ribosomal DNA Restriction Analysis (ARDRA). From the 218 isolated strains, 27 were identified as S. aureus (12\%), four of them were resistant to oxacillin and two of them were classified as MRSA (Methicillin-resistant S. aureus). The prevalence of isolated strains among animal personnel care was low (2\%) but all MRSA isolates were found among the clinical staff. Results of ARDRA pointed out that $S$. aureus strains isolated from different animal care personnel were grouped in the same cluster when HindIII and HinfII restriction enzymes were used. When ARDRA was performed with HaeIII enzyme, the formation of two clusters was observed, but the isolated strains were not correlated. The prevalence of $S$. aureus strains isolated was higher in clinical staff and the biochemical and molecular assays of them presented $100 \%$ of correlation.
\end{abstract}

Keywords: Staphylococcus aureus. ARDRA. mecA gene. MRSA.

\section{Resumo}

Staphylococcus aureus está entre os microrganismos que apresentam as maiores taxas de morbidade e mortalidade em seres humanos e animais. Linhagens de $S$. aureus resistentes a meticilina podem causar surtos de infecção em todo o mundo, o que contribui para a escassez de arsenal terapêutico. Este trabalho analisou o perfil epidemiológico de estirpes de $S$. aureus isoladas de pessoas que trabalham em contato com animais em um hospital veterinário com gado leiteiro e também em amostras de leite de vacas acometidas por mastite. As estirpes de S. aureus isoladas foram caracterizadas fenotipicamente por meio de antibiograma, testes de catalase e coagulase, e pelo teste de Voges-Proskauer. As amostras também foram caracterizadas genotipicamente pela técnica de Análise de Restrição de DNA Ribossômico Amplificado (ARDRA-PCR). Das 218 estirpes isoladas, 27 foram identificadas como S. aureus (12\%). Entre essas, quatro estirpes foram resistentes à oxacilina e duas classificadas como SARM (S. aureus resistente à meticilina). A ocorrência de estirpes de S.aureus isoladas entre o pessoal que trabalha em contato com os animais foi baixa (2\%), mas estirpes identificadas como SARM foram encontradas na equipe clínica. As análises de ARDRA realizadas com as enzimas de restrição HindIII e HinfII demonstraram que S. aureus isolados de diferentes indivíduos que trabalhavam com animais foram agrupados no mesmo cluster. Quando a ARDRA foi realizada com HaeIII foi observada formação de dois grupos, mas os isolados não se correlacionaram. Conclusão: a ocorrência de estirpes de $S$. aureus isoladas foi maior na equipe clínica, apresentando também correlação de 100\% nos ensaios bioquímicos e moleculares.

Palavras-chave: Staphylococcus aureus. ARDRA. mecA gene. SARM. 
Correspondence to:

Adriana Fiorini

Universidade Federal do Paraná, Setor Palotina, Departamento

de Biociências

Rua Pioneiro, 2153

CEP 85950-000, Palotina, PR, Brazil

e-mail: drifiorini@gmail.com

Received: 1/6/2016

Approved: 12/5/2017

\section{Introduction}

Staphylococcus aureus is the major mastitis pathogen causing significant losses in the dairy industry (OTE et al., 2011; KHICHAR et al., 2012). Moreover it is considered as a ubiquitous human pathogen and is also responsible for invasive aggressive infections. This bacterium was already formerly susceptible to semi-synthetic penicillinase-resistant $\beta$-lactams (methicillin; oxacillin). The methicillin-resistant $S$. aureus (MRSA) is cross-resistant to all $\beta$-lactams, including cephalosporins and penicillin (DAKA et al., 2012).

Resistance to antimicrobials can be acquired by plasmid transfer between strains and by the discriminated use of antimicrobial drugs due to production of a supplemental penicillin-binding protein (PBP2'-PBP2a), which presents low affinity with semi synthetic penicillin encoded by the mec $A$ gene. Inactivation of oxacillin by $\beta$-lactamase hyperproduction and the production of modified intrinsic PBPs with affinity for altered oxacillin (MOD-SA) can be some of the causes for borderline resistance (PEREIRA et al., 2009).

Animal infection with MRSA was also reported (PANTOSTI, 2012). The transmission between animals and humans causing MRSA colonization has already been reported (LEE, 2003; HANSELMAN et al., 2006; WULF et al., 2006), including among veterinarians and dairy cattle producers (SEARS; MCCARTHY, 2003; BROUILLETTE; MALOUIN, 2005).

The first reported case of isolation of MRSA was performed in samples of cow milk with mastitis (DEVRIESE et al., 1972), and since then other cases have been reported in animals including sheep, cats, cattle, dogs, rabbits, birds, and horses (BAPTISTE et al., 2005; OTE et al., 2011; PERILLO et al., 2012). Loeffler et al. (2005) isolated strains of MRSA from veterinary clinical staff and from dogs in a veterinary hospital. The authors suggested that daily exposure to pets may represent a risk factor for colonization and that more studies are needed in order to determine whether veterinarians and people who live or work with pets have any risk of carrying these strains. The emergence of MRSA may be a risk factor for veterinarians (HANSELMAN et al. 2006), since more than $10 \%$ may be colonized and may suffer with the colonization of this bacterium, according to the British Small Animal Association (BSAVA, 2014).

Information on the frequency of occurrence and epidemiology of etiologic agents are critical for the development of special programs that could be applied for controlling the dissemination of $S$. aureus strains (GRISOLD et al., 2002; DUARTE et al., 2005).

S. aureus can be phenotypically identified by growth characteristics and subsequent detection of catalase and coagulase activities (GRISOLD et al., 2002) and its resistance can be detected by conventional susceptibility tests using oxacillin $(6 \mu \mathrm{g} / \mathrm{mL})$ and cefoxitin $(30 \mu \mathrm{g})$ antibiotic disks on sheep blood agar (CLSI, 2013) or Baird-Parker Agar (SON et al., 2010). The main disadvantages of these techniques are the false positives results and being too much time-consuming, as long as the promotion of bacteria growth is prior. The MRSA prevalence study by morphological and biochemical conventional analyses such as antibiogram presents some advantages such as simplicity and a widespread use, but they have limitations, such as requiring a minimum of $36 \mathrm{~h}$ to set up, and the presence of viable bacteria. It also suffers with the interference of other microorganisms and environmental factors that cause inaccurate results (OMAR et al., 2014).

Molecular identification of MRSA can be performed by Polymerase Chain Reaction (PCR) amplification of mecA gene coding for low-affinity penicillin-binding protein, PBP 2 (GRISOLD et al., 2002) and $c o A$ gene coding for coagulase protein (SANJIV et al., 2008) using specific primers. This technique can offer high efficacy and safety, and it may be considered as a fast and sensitive method, using low amounts of DNA template in a given sample (BAPTISTE et al., 2005; O'MAHONY et al., 2005).

In addition to that, studies of intraspecific biodiversity of $S$. aureus can be performed using the amplified ribosomal DNA restriction analysis (ARDRA), which reveals restriction DNA fragments polymorphisms and shows the rRNA phylogenetic patterns by the degree of conservation of restriction sites (HOPPE-SEYLER et al., 2004; NEMA et al., 2007; HAN et al., 2008).

The objective of this work was to investigate the occurrence of $S$. aureus in veterinary personnel, people that work directly in dairy cattle, and also in dairy cattle affected by mastitis, as well as to characterize the isolates by phenotypic and genotypic assays. 


\section{Material and Methods}

\section{Sampling from veterinary personnel and animals}

This study analyzed 128 milk samples collected from 70 cows with mastitis (California Mastitis Test positive, whose samples were collected separately from each mammary gland), from 11 dairy farms located in three different cities in the state of Parana, Brazil (Palotina, Itaipulândia, and Missal); and 90 swab samples collected from the anterior nares of human (68 samples were from a Veterinary Teaching Hospital staff, including vet students, professors, and cleaning employees, and 22 from dairy workers who have direct contact with cattle). The samples were collected from September 2007 to March 2008.

\section{Phenotypic characterization}

The 218 samples collected were plated on mannitol salt agar and blood agar medium, incubated at $35-37^{\circ} \mathrm{C}$ from 18 to $24 \mathrm{~h}$ under aerobic conditions. The Gram-positive cocci isolated were tested for catalase and the ones tested positive were identified by coagulase test tube and mannitol fermentation.

In order to distinguish micrococci and staphylococci from other related species, the samples were tested for their sensitivity to furazolidone $(100 \mu \mathrm{g})$ in Müeller-HintonAgar solid medium. The differentiation of S. aureus from other coagulase-positive species was performed by the Voges-Proskauer test (LOEFFLER et al., 2005).

Antimicrobial susceptibility of 21 positive isolates of $S$. aureus was tested by disk diffusion method on solid medium (Müeller-Hinton Agar), following the criteria of the Clinical and Laboratory Standards Institute (CLSI, 2013), using antibiotic discs of amikacin $(30 \mu \mathrm{g})$, cefepime $(30 \mu \mathrm{g})$, clindamycin $(2 \mu \mathrm{g})$, chloramphenicol $(30 \mu \mathrm{g})$, erythromycin $(15 \mu \mathrm{g})$, amoxicillin $(10 \mu \mathrm{g})$, norfloxacin $(10 \mu \mathrm{g})$, oxacillin $(1 \mu \mathrm{g})$, penicillin $\mathrm{G}(10 \mathrm{IU})$, and vancomycin $(30 \mu \mathrm{g})$.

\section{Molecular analyses}

\section{PCR assay for detection of Coa and mecA genes}

DNA was isolated from $22 \mathrm{~S}$. aureus isolated strains from clinical staff by phenol-chloroform method according to Matthews et al. (1997), with some modifications. A volume of $1 \mathrm{~mL}$ from a bacterial growth in Voges-Proskauer broth after incubation for $48 \mathrm{~h}$ at $37^{\circ} \mathrm{C}$ of each isolate was transferred to a microtube. After centrifugation at 10,000 $\mathrm{g}$ for $10 \mathrm{~min}$, lysis of cells was achieved by addition of 80 $\mu \mathrm{g} / \mathrm{ml}$ of lysozyme in buffer containing $10 \mathrm{mM}$ Tris- $\mathrm{HCl}$ $\mathrm{pH}$ 8.0, 0.1 M NaCl, $1 \mathrm{mM}$ EDTA pH 8.0, and 5\% Triton $\mathrm{X} 100$, followed by vigorous agitation. Samples were kept on ice for $2 \mathrm{~min}$ and sonicated for $3 \mathrm{~min}$ (16 times). Then, proteinase $\mathrm{K}$ at $77 \mu \mathrm{g} / \mathrm{ml}$ in buffer containing $12 \mathrm{mM}$ Tris$\mathrm{HCl} \mathrm{pH} \mathrm{8.0,0.5 \%} \mathrm{sodium} \mathrm{dodecyl} \mathrm{sulfate} \mathrm{was} \mathrm{added} \mathrm{and}$ the samples were vigorously agitated. A total of $3 \mu \mathrm{l}$ of $20 \mathrm{mg} / \mathrm{ml}$ proteinase $\mathrm{K}$ was added and further incubation at $37^{\circ} \mathrm{C}$ was performed for $1 \mathrm{~h}$. Protein precipitation, phenolchloroform extraction, and DNA precipitation were made according to the original protocol. The presence of a $310 \mathrm{bp}$ band corresponding to the $m e c A$ gene was verified by PCR, according to Pérez-Roth et al. (2001) as follows: amplification of the mecA gene was performed using the primers MecA1 (5'-GTAGAAATGACTGAACGTCCGATAA-3') and MecA2 (5'-CCAATTCCACATTGTTTCGGTCTAA-3'). Coa-F amplification was performed according to Kearns et al. (2001), using the primers Coa-R (5'-GTAGATTGGGCAATTACATTTTGGAGG-3') and (5'-CGCATCAGCTTTGTTATCCCATGTA-3') yielding a $117 \mathrm{bp}$ band. The reaction mixture $(20 \mu \mathrm{l}$ final volume) consisted of $1 \mathrm{x}$ PCR buffer, $2.5 \mathrm{mM} \mathrm{MgCl} 2,0.5 \mu \mathrm{M}$ of each primer, $1 \mathrm{mM}$ of dNTP mix, $1 \mathrm{U}$ Taq Polymerase (Promega Madison, WI), and a $30 \mathrm{ng}$ DNA template. Amplification was performed under the following amplification conditions: 1 cycle of $94^{\circ} \mathrm{C}$ for $5 \mathrm{~min}, 35$ cycles of $94^{\circ} \mathrm{C}$ for $60 \mathrm{~s}, 1$ cycle of $57^{\circ} \mathrm{C}$ for $60 \mathrm{~s}$ and $72^{\circ} \mathrm{C}$ for $60 \mathrm{~s}$ each, and a final extension cycle of $72^{\circ} \mathrm{C}$ for $7 \mathrm{~min}$. PCR products were examined by electrophoresis in a 1.5\% agarose gel. S. aureus ATCC 43300 (oxacillin resistant) was used as positive control.

\section{Amplified ribosomal DNA restriction analysis (ARDRA)}

DNA was isolated from 24 S. aureus strains isolated (19 from clinical staff, two from farm workers, three from cattle milk, one from MRSA negative and one from MRSA positive strain), as described above. PCR amplification of $1,500 \mathrm{bp}$ fragment of the $16 \mathrm{~S} \mathrm{rDNA}$ was performed with the primers Y1F (5'-TGGCTCAGAACGAACGCTGGCGGC-3') and Y3R (5'-TACCTTGTTACGACTTCACCCCAGTC-3') (YOUNG et al., 1991; CRUZ et al., 2001).

PCR was conducted in a Bioer Life Express thermal cycler. The reaction mixture ( $25 \mu \mathrm{L}$ final volume) consisted of $1 \mathrm{x}$ buffer, $0.2 \mathrm{mM} \mathrm{MgCl}_{2}, 0.2 \mu \mathrm{M}$ of each primer, $0.4 \mathrm{mM}$ of dNTP mix, 1 U Taq Polymerase (Promega Madison, WI), and a $30 \mathrm{ng}$ DNA template. The amplification conditions were: 1 cycle of $94^{\circ} \mathrm{C}$ for $5 \mathrm{~min}, 30$ cycles of $94^{\circ} \mathrm{C}$ for $45 \mathrm{~s}$, 
1 cycle of $57^{\circ} \mathrm{C}$ for $45 \mathrm{~s}$, and $72^{\circ} \mathrm{C}$ for $45 \mathrm{~s}$ each, as well as a final extension cycle of $72^{\circ} \mathrm{C}$ for $5 \mathrm{~min}$. PCR products were examined by electrophoresis in a $1.5 \%$ agarose gel. The DNA templates extracted from all of the strains produced a single band of approximately $1,500 \mathrm{bp}$.

Amplified 16rRNA gene fragments $(15 \mu \mathrm{L})$ were digested with $10 \mathrm{U}$ of different restriction endonucleases HindIII, HaeIII, Hinfl, from New England BioLabs (Frankfurt, Germany) in a final reaction (one for each enzyme) volume of $20 \mu \mathrm{L}$ at $37^{\circ} \mathrm{C}$ for three hours. Restriction fragments were separated by $1.5 \%(\mathrm{w} / \mathrm{v})$ agarose gel electrophoresis at $120 \mathrm{~V} /$ $\mathrm{cm}$ for $1.5 \mathrm{~h}$ in $1 \mathrm{x}$ TBE buffer ( $89 \mathrm{mM}$ Tris base, $89 \mathrm{mM}$ Boric acid, $2 \mathrm{mM} \mathrm{EDTA}$ ) and visualized by staining with ethidium bromide $(0.5 \mu \mathrm{g} / \mathrm{ml})$ and photographed under UV light $(260$ $\mathrm{nm})$. A 100 bp DNA Ladder (Ludwig Biotecnologia LTDA) and a $1 \mathrm{~kb}$ DNA Ladder (Promega, Madison, WI) were used as a standard for molecular size determination.

The ARDRA patterns were analyzed by the Bionumerics version 6.1 software packages (Applied Maths, Belgium). Similarities of the digitized profiles were calculated using Jaccard correlation and an average linkage UPGMA (Unweighted Pair-Group Method Using Arithmetic Averages) dendrogram was obtained.

\section{Results, Discussion and Conclusions}

Bovine mastitis (inflammation of the mammary gland) is a major disease affecting dairy herds around the world, and S. aureus is recognized as one of the most frequently isolated pathogen in cases of subclinical mastitis and listed as one of the most contagious microorganisms causing subclinical mastitis (FERREIRA et al., 2006; FREITAS et al., 2006).

It has been frequently suggested that certain strains of $S$. aureus easily colonize patients and medical staff (FANOY et al., 2009). Nasal carrier's studies are important in order to define control measures (VON EIFF, 2001; KUEHNERT et al., 2006).

\section{Prevalence and microbiological analysis of S. aureus}

In the present investigation, a total of 218 samples were collected, including 128 milk samples from 70 cows tested positive by California Mastitis Test and 90 nasal swabs from human beings. Sixty-eight nasal swabs were collected from the veterinary hospital staff and 22 from dairy workers who have direct contact with cattle. The presence of $S$. aureus was confirmed by biochemical tests in 27 of the 218 analyzed samples (Table 1). Among the three different sources, the highest frequency of occurrence of $S$. aureus was in the veterinary hospital staff (32\%) against $9 \%$ in farm workers and $2 \%$ in the milk of bovines with mastitis. According to Sakwinska et al. (2011) the main niche and the largest reservoir of S. aureus are human nares. Radwan et al. (2015) reported that not only the contact of diseased animals and healthy humans can lead to disease transmission, but also the possibility of plasmid transference carrying antibiotic resistance genes between strains of different sources.

Table 1 - Source of the 218 samples used in this study, the respective occurrence of Staphylococcus aureus isolated from the three different sources and the oxacillin susceptibility profile of the bacteria - state of Paraná - Brazil (Samples collected from Sept. 2007 to Mar. 2008)

\begin{tabular}{lcccc}
\hline \multicolumn{1}{c}{ Groups } & $\begin{array}{c}\text { Total samples } \\
\text { collected }\end{array}$ & S. aureus positive & Oxacillin resistance \\
\cline { 4 - 5 } * Cattle milk & 128 & $3(2 \%)$ & 0 & Negative \\
${ }^{\S}$ Farm workers & 22 & $2(9 \%)$ & 0 & $3(100 \%)$ \\
${ }^{\S}$ Clinic staff & 68 & $22(32 \%)$ & $2(9 \%)$ & $2(100 \%)$ \\
Total & 218 & $27(12 \%)$ & $2(7 \%)$ & $25(91 \%)$ \\
\hline
\end{tabular}

* Collected from 70 cows with mastitis from 11 dairy farms of three cities of Parana State, Brazil

$\S$ Swabs samples collected from the anterior nares of human

The present results pointed out a frequency of occurrence of $12 \%$ of $S$. aureus from the total number of isolated strains in the groups evaluated (Table 1). In a study conducted in the United States (KUEHNERT et al., 2006) with more than nine thousand people, the prevalence for people colonized by S. aureus was 32\%. Sakwinska et al. (2011), in a study on S. aureus isolated from bovine milk samples received by a diagnostic veterinary laboratory at the Institute Galli-Valerio, in Western Switzerland, reported that every third person is colonized with this 
facultative pathogen, which could represent two billion people colonized by this pathogen around the world.

The clinical staff showed the highest prevalence of this bacterium (32\%) among the groups evaluated (Table 1). Several authors commented a higher prevalence of microorganisms in hospital workers compared to other communities. In Malaysia, a study conducted in a rural hospital revealed a higher rate of staphylococcal carriage: $55 \%$ in patients and $76 \%$ in hospital staff (SOON, 1986). Also in Malaysia, Santhosh et al. (2007) found a prevalence of $23 \%$ among healthy students in the first years of medical school. In the United States, Bischoff et al. (2004) reported $29 \%$ frequency of occurrence for nasal carriers of S. aureus in a similar study with 450 students of medical school students. S. aureus is the major etiological agent related to mastitis. Sá et al. (2004) observed that, out of 1622 cows from 20 dairy farms located in the municipalities of the state of São Paulo, S. aureus was isolated in $21 \%$ of the animals with mastitis. Freitas (2006) in a similar study described that the frequency of occurrence of $S$. aureus isolated from both mastitis-affected cows' milk and curd cheese from Pernambuco, Brazil, was 13.6\%. While in a similar study, Anderson et al. (2012) observed 13\% of S. aureus in milk samples from lactating herd cows from 3 southeastern US dairy farms. The results pointed out that animal care personnel are more exposed to $S$. aureus and that the high exposition can increase cases of this bacterial infection. The results obtained in the present investigation showed a frequency of occurrence of $2 \%$ of $S$. aureus in the evaluated milk samples, representing a low value compared to other studies. However, the frequency of occurrence of this agent in cows with mastitis could range from $9.1 \%$ to 85\% (WILSON et al., 1997; RABELO et al., 2013).

\section{Antimicrobial resistance patterns}

Antibiograms were evaluated among the $S$. aureus strains isolated. The obtained results showed four resistant (19\%) and 17 sensitive (81\%) strains to oxacillin by the disk diffusion technique on solid media. The resistance profile for ten antibiotics tested in 21 samples showed a high resistance of the strains to penicillin and amoxicillin and great effectiveness of the following drugs: amikacin, cefepime, chloramphenicol, oxacillin, norfloxacin, and vancomycin (100\% susceptibility) (Table 2$)$.

Table 2 - The resistance and sensibility profile for ten antibiotics tested in 21 samples of $S$. aureus isolated from cattle milk or nasal swab from farm workers and vet clinical staff in this study - state of Paraná - Brazil (Samples collected from Sept. 2007 to Mar. 2008)

\begin{tabular}{lccc}
\hline \multicolumn{1}{c}{ Antibiotic } & Resistant samples (\%) & Sensitive samples (\%) & Total samples \\
\hline Amikacin & $2(9.5)$ & $19(90.5)$ & 21 \\
Cefepime & $7(33)$ & $14(67)$ & 21 \\
Clindamycin & $11(53)$ & $10(47)$ & 21 \\
Chloramphenicol & $2(10)$ & $17(90)$ & 19 \\
Erythromycin & $11(52)$ & $10(48)$ & 21 \\
Amoxicillin & $16(84)$ & $3(16)$ & 19 \\
Norfloxacin & $4(21)$ & $15(79)$ & 19 \\
Oxacillin & $4(19)$ & $17(81)$ & 21 \\
Penicillin G & $17(89)$ & $2(11)$ & 19 \\
Vancomycin & $0(0)$ & $21(100)$ & 21 \\
\hline
\end{tabular}

The $S$. aureus strains isolated were resistant to amoxicillin and penicillin (> 80\%). The resistance pattern of microorganisms isolated in the community reflects the frequency with which these antibiotics are used in that population. Penicillin-susceptible strains are quite rare. Menegotto and Picoli (2007) found 100\% resistance to penicillin researching nasal $S$. aureus strains isolated from community (non-hospitalized individuals), in Novo
Hamburgo-RS. Moreover, Zavadinack et al. (2001) found a ratio of $91 \%$ - similar to those in this study - in infected patients with skin and subcutaneous cell-tissue abscesses at the University Hospital of the State University of Maringá, state of Paraná.

Hanselman et al. (2006) found MRSA strains in 6.5\% attendees at an international veterinary conference, held in Baltimore, Maryland, USA. In Canada, Weese et al. (2006) 
found that $9.7 \%(10 / 103)$ of the veterinary hospital staff members of large animals were colonized by MRSA strains. In the present investigation, MRSA strains were found in $9 \%(2 / 22)$ of hospital staff and no MRSA positive strains were detected among others classes.

\section{ARDRA genotyping of $S$. aureus}

The amplification of mecA gene by PCR was positive (310 bp amplicon) in only two isolates from clinical staff. All samples resulted in amplification of Coa fragment (117 bp), Figure 1.

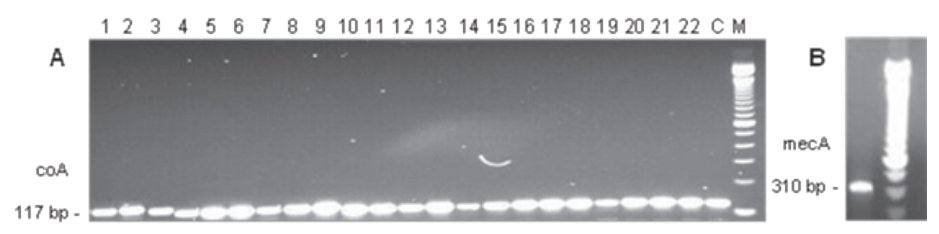

Figure 1 - PCR-amplified 117 bp fragment from Coa region (Gel A) of the 22 samples of S. aureus from clinical staff, showed in Table 1, and $310 \mathrm{pb}$ fragment from mecA region (Gel B) from one of the two positive S. aureus MRSA. Sample C: S. aureus MRSA positive control. Gels were separated in 1.5\% agarose gels. M. 100 bp DNA Ladder (Invitrogen)

Phenotypic characterization has some restrictions: the time required to reach the results, the need for viable bacteria, interference from other microorganisms and environmental factors in the culture medium that can generate inaccurate results. Molecular methods such as PCR can reduce the time required to obtain them and increase the reliability of the results. However, molecular methodology has the advantage of being faster and more accurate for Staphylococcus aureus Methicillin Resistant (MRSA) identification.

Twenty-four of 27 strains of Staphylococcus aureus isolated from the three different sampling sources (clinical staff, farm workers, and cattle milk) were further studied for any intraspecific strain variation using 16S ARDRA upon digestion with HaeIII, HindIII, and HinfI restriction enzymes. Three strains were not included in this analysis because they could not reach the bacterial concentration required by the test. A MRSA negative (sample 28) strain and a MRSA positive (sample 29) strain were used as control.

Isolates yielded single amplification products of the expected size (about 1,500 bp) for the 16S rRNA genes. Figures $2 \mathrm{~A}-\mathrm{C}$ show the molecular profiles for the restriction enzymes HaeIII, HindIII, and Hinfl, respectively. Enzymatic digestion of amplicons obtained by independent analyses always yielded the same ARDRA patterns, thus showing the reproducibility of the procedure.
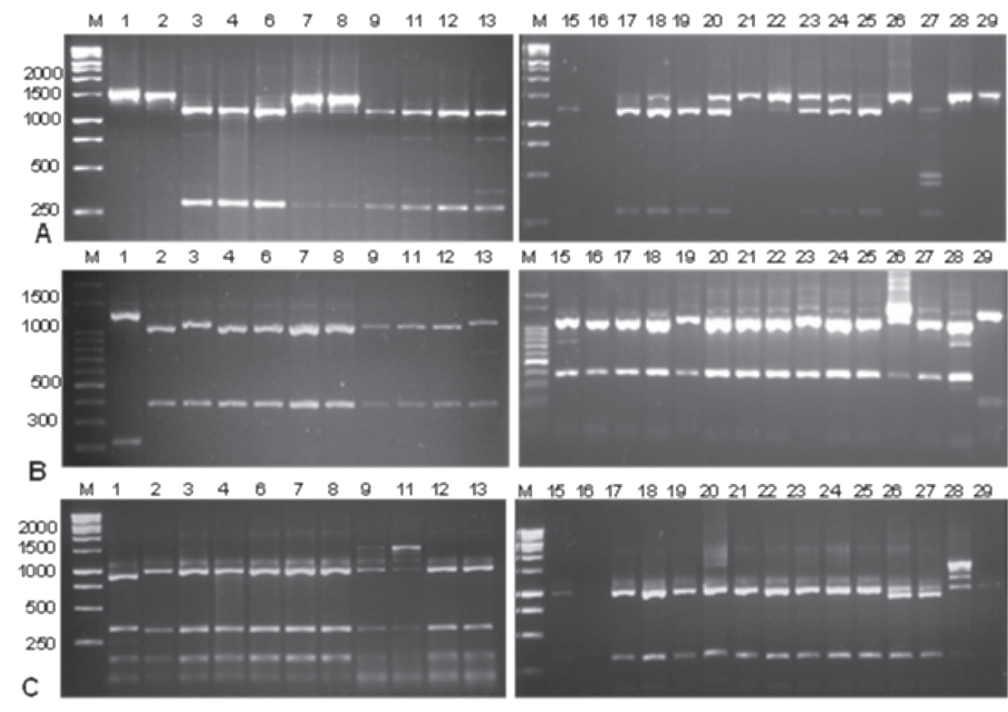

Figure 2 - ARDRA patterns of the PCR-amplified 16S rDNA fragment obtained by digestion with the enzymes HaeIII (A), HindIII (B), and HinfII (C) separated in 1.5\% agarose gels of 24 out of 27 Staphylococcus aureus isolated strains, from the three different sampling sources - clinical staff (samples 1, 2, 3, 4, 6, 7, 8, 9, 11, 12, 13, 15, 16, 17, 18, 19, 20, 21, 22), farm workers (samples 23 and 24), cattle milk (samples 25, 26 and 27). Each letter corresponds to a different restriction pattern of the different isolates. The control samples 28 and 29 correspond to the MRSA negative and positive strains, respectively. M. 1 kb DNA Ladder (Promega, Madison, WI) (Gels A and C) and 100 bp DNA Ladder (Ludwig Biotecnologia LTDA) (Gel B) 
The figures depict that only a limited number of patterns were obtained with each enzyme. Thus, only two fragment patterns were obtained when HaeIII and HindIII were used. The maximum number of fragment patterns was obtained with Hinfl, which produced three bands. Fragments smaller than $200 \mathrm{bp}$ that could not be properly visualized were excluded from the analyses.

The Jaccard/UPGMA analysis (Figure 3) showed that the majority of the isolated strains appeared in closely linked clusters obtained for each restriction pattern, which showed higher similarity values. The isolated strains of S.aureus showed the fragment patterns suggesting that ARDRA may not be suitable for intraspecific differentiation. The sample 16 was not included in the dendrogram analyses using the HaeIII and HinfIII restriction enzymes because it showed a weak band pattern.
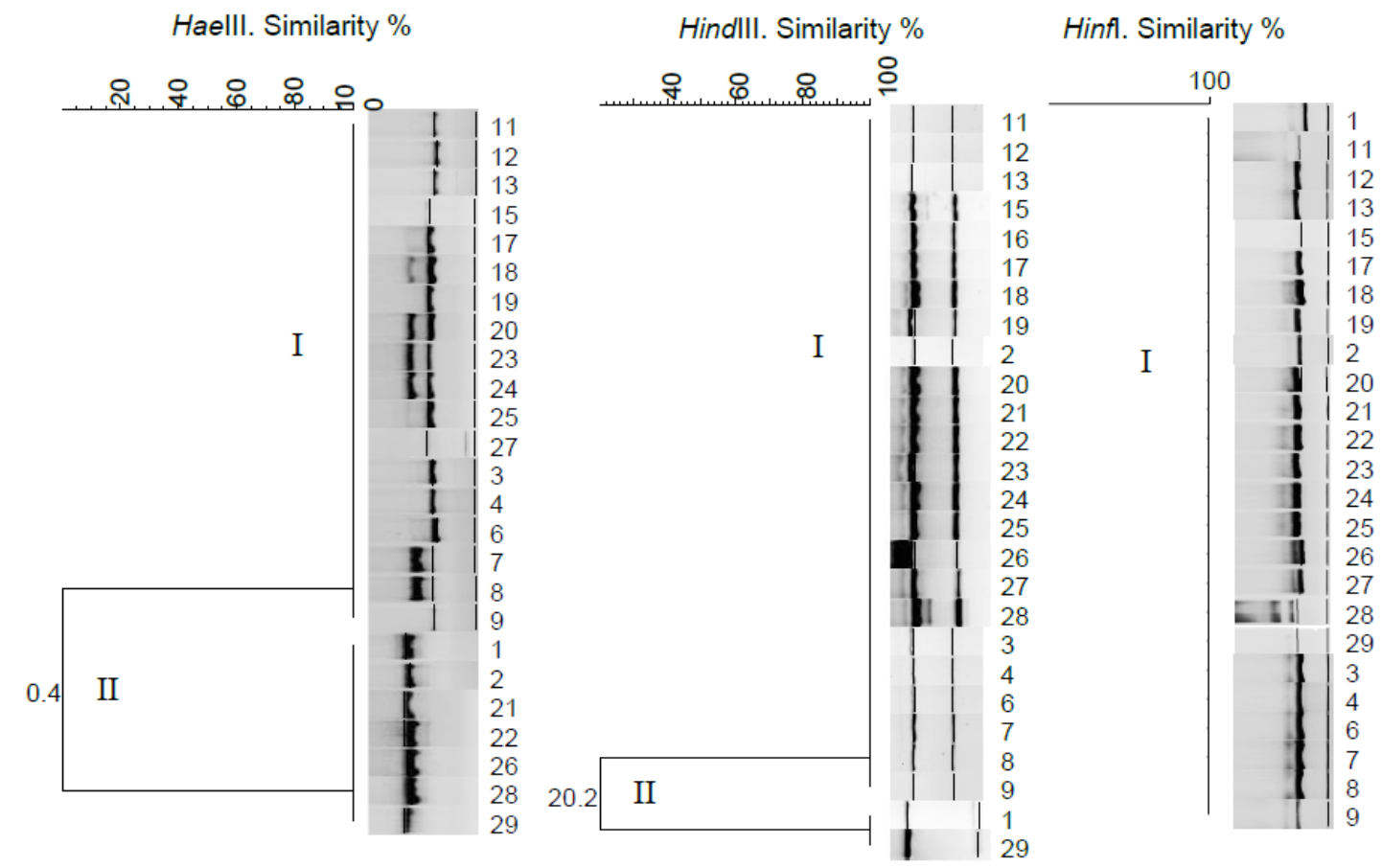

Figure 3 - Amplified ribosomal DNA restriction analysis (ARDRA) of 24 out of 27 Staphylococcus aureus isolated strains, from the three different sampling sources (clinical staff, farm workers and cattle milk). The dendrograms based on analysis of restriction patterns of $16 \mathrm{~S}$ rDNA obtained from HaeIII, HindIII, and Hinfl restriction enzymes were constructed using the Jaccard correlation and an average linkage UPGMA Bionumerics version 6.1 software packages (Applied Maths, Belgium). The following settings were used: optimization: $2 \%$ and position tolerance: $4 \%$. The clusters are indicated by Roman numerals

The profile obtained with the enzyme HaeIII allowed the formation of two distinct clusters (I and II) in the 25 analyzed samples, including both control samples (MRSA positive and negative), which grouped $72 \%$ (18) and $18 \%$ (7) of samples, respectively. The positive control grouped with the isolated strains of the minor group. The similarity values are indicated for each cluster in the dendrogram. The isolated strains of each cluster presented $100 \%$ similarity between them. The level of similarity of the strains belonging to both clusters was very low $(0.4 \%)$.

The profile obtained with the enzyme HindIII also allowed the formation of two distinct clusters (I and II) in the 26 analyzed samples, which grouped $92 \%$ (23) and $8 \%$
(2) of samples, respectively. The positive control standard strain, number 29 , and the strain number 1 , isolated from clinical staff swab, were grouped in the cluster II. The strains included in each cluster presented $100 \%$ of similarity. The level of similarity between the isolated strains in the two clusters was $20.2 \%$. The formation of one unique cluster in the 25 analyzed samples, which grouped all the strains with $100 \%$ similarity, was observed in the Hinfl generated profile.

In summary, when ARDRA was performed with HindIII and HinflI restriction enzymes, samples isolated from nasal swab of farm workers, nasal swab of Veterinarian Hospital clinical staff, cattle milk, and MRSA samples were grouped in the same cluster. When HaeIII restriction enzyme was 
used, the strains isolated from nasal swab of Veterinarian Hospital clinical staff and from cattle milk were distributed into two dendrogram clusters (I and II).

Overall, the isolated strains, irrespective of their isolation source, showed almost the same band patterns within species, using each one of the three restriction enzymes applied. Although each of the three restriction endonucleases produced different pattern of bands, none of them could differentiate the $S$. aureus strains isolated.

ARDRA seems to be more appropriate to differentiate and characterize the microorganisms at interspecific, rather than intraspecific level, whether associated or not with $16 \mathrm{~S}$ sequencing (VANEECHOUTTE et al., 1995; SANDES et al., 2014; ÖZTÜRK; METERELLIYÖZ, 2015). However, restriction analysis pattern of the $16 \mathrm{~S}$ rRNA gene appeared to be of limited value in other genera.

Although ARDRA analysis of the 16S-23S rDNA does not seem to have potential for intraspecific differentiation of $S$. aureus, it was a rapid and technically relatively simple method to recognize other bacterial strains as Mycoplasma mycoides (KUMAR et al., 2013) and other bacteria (DOBNER et al., 1996; ROTH et al., 2000; JENG et al., 2001; BORSODI et al., 2015; ÖZTÜRK; METERELLIYÖZ, 2015). ARDRA has been previously used to detect intraspecific variation among high-level gentamicin-resistant enterococci (Enterococcus faecalis) (INGIANNI et al., 1997).

Until now there are few reports investigating $16 \mathrm{~S}$ differences of $S$. aureus strains applying the ARDRA technique. Nema et al. (2007) found no difference in 16 S region in S. aureus strains isolated from food and clinical samples in the Indian subcontinent, claiming that the strains were clonal in origin. Hoppe-Seyle et al. (2004) used ARDRA to discriminate different species of Staphylococcus. The apparent lack of heterogeneity when certain restriction enzymes were used could not imply in the absence of mutations, but may simply indicate that ARDRA and other RFLP-based methods are relatively insensitive to mutations between the recognition sites. Also, the 16S rDNA sequences show low intraspecies variability if compared to most protein encoding genes, which justifies their use in the construction of phylogenetic topologies (WOESE et al., 1980).

Additional strategies to testing ARDRA potential for the discrimination of $S$. aureus strains could include cloning of PCR products and further sequencing, in order to to combine ARDRA with other fingerprint techniques such as RAPD, and to test the efficient of ARDRA in discriminated intraspecies strains using more restriction enzymes.

In conclusion, the prevalence of $S$. aureus strains was higher in the Veterinarian Hospital staff than in farm workers and in bovines with mastitis. ARDRA was not able to reveal genotypic differences among the isolates, which, regardless of their isolation source, presented almost the same band patterns within species. It is expected that results from the current study will improve therapeutic guidelines that could avoid infection of $S$. aureus in veterinary hospitals. In addition to that, such recommendations can also be used to develop specific strategies of prevention of S. aureus transmission.

\section{Conflict of Interest}

The authors did not declare any conflict of interest.

BISCHOFF, W. E.; WALLIS, M. L.; TUCKER, K. B.; REBOUSSIN, B. A.; SHERERTZ, R. J. Staphylococcus aureus nasal carriage in a student community: prevalence, clonal relationships, and risk factors. Infection Control \& Hospital Epidemiology, v. 25, n. 6, p. 485-491, 2004. doi: $10.1086 / 502427$.

BORSODI, A. K.; BÁRÁNY, Á.; KRETT, G.; MÁRIALIGETI, K.; SZILI-KOVÁCS, T. Diversity and ecological tolerance of bacteria isolated from the rhizosphere of halophyte plants living nearby Kiskunság soda ponds, Hungary. Acta Microbiologica 
et Immunologica Hungarica, v. 62, n. 2, p. 183-197, 2015. doi: 10.1556/030.62.2015.2.8.

BRITISH SMALL ANIMAL VETERINARY ASSOCIATION (BSAVA). 2014. Available from: < https:// goo.gl/2s6T8N>. Viewed: 19 June 2017.

BROUILLETTE, E.; MALOUIN, F. The pathogenesis and control of Staphylococcus aureus-induced mastitis: study models in the mouse. Microbes and Infection, v. 7, n. 3, p. 560-568, 2005. doi: 10.1016/j.micinf.2004.11.008.

\section{CLINICAL AND LABORATORY STANDARDS} INSTITUTE (CSLI). M100-S23 - Performance standards for antimicrobial susceptibility testing; twenty-third informational. v. 33, n. 1, p. 1-206, 2013. Supplement.

CRUZ, L. M.; SOUZA, E. M.; WEBER, O. B.; BALDANI, J. I.; DÖBEREINER, J.; PEDROSA, F. O. 16S ribosomal DNA characterization of nitrogen-fixing bacteria isolated from banana (Musa spp.) and pineapple (Ananas comosus (L.) Merril). Applied and Environmental Microbiology, v. 267, n. 5, p. 2375-2379, 2001. doi: 10.1128/AEM.67.5.23752379.2001.

DAKA, D.; G/SILASSIE, S.; YIHDEGO, D. Antibioticresistance Staphylococcus aureus isolated from cow's milk in the Hawassa area, South Ethiopia. Annals of Clinical Microbiology and Antimicrobials, v. 11, n. 26, 2012. doi: 10.1186/1476-0711-11-26.

DEVRIESE, L. A.; VAN DAMME, L. R.; FAMEREE, L. Methicillin (cloxacillin)-resistant Staphylococcus aureus strains isolated from bovine mastitis cases. Zentralblatt für Veterinarmedizin Reihe B, v. 19, n. 7, p. 598-605, 1972. doi: 10.1111/j.1439-0450.1972.tb00439.

DOBNER, P.; FELDMANN, K.; RIFAI, M.; LÖSCHER, T.; RINDER, H. Rapid identification of mycobacterial species by PCR amplification of hypervariable $16 \mathrm{~S}$ rRNA gene promoter region. Journal of Clinical Microbiology, v. 34, n. 4, p. 866-869, 1996.

DUARTE, R. S.; BELLEI, B. C.; MIRANDA, O. P.; BRITO, M. A.; TEIXEIRA, L. M. Distribution of antimicrobial resistance and virulence-related genes among Brazilian group B streptococci recovered from bovine and human sources. Antimicrobial Agents and Chemotherapy, v. 49, n. 1, p. 97-103, 2005. doi: 10.1128/AAC.49.1.97-103.2005.

FANOY, E.; HELMHOUT, L. C.; VAN DER VAART, W. L.; WEIJDEMA, K.; VAN SANTEN-VERHEUVEL, M. G.; THIJSEN, S. F.; DE NEELING, A. J.; VAN WAMEL, W. J.; MAŇÁSKOVÁ, S. H.; KINGMA-THIJSSEN, J. L. An outbreak of non-typeable MRSA within a residential care facility. Eurosurveillance, v. 14, n. 1, 2009.

FERREIRA,L.M.; FILHO,A. N.; OLIVEIRA, E.;ZAFALON, L. F; DE SOUZA, V. Variabilidades fenotípica e genotípica de estirpes de Staphylococcus aureus isoladas em casos de mastite subclínica bovina. Ciência Rural, v. 36, n. 4, p. 12281234, 2006. doi: 10.1590/S0103-84782006000400028.

FREITAS, M. F. L. Caracterização fenotípica e genotípica de Staphylococcus spp. isolados de queijo de coalho e leite de vacas com mastite no estado de Pernambuco, Brasil. 2006. Tese (Doutorado em Nutrição) - Centro de Ciências da Saúde, Universidade Federal de Pernambuco, Recife, 2006. Available from: <https:/goo.gl/CEPUzG>. Viewed: 19 jun. 2017.

GRISOLD, A. J.; LEITNER, E.; MÜHLBAUER, G.; MARTH, E.; KESSLER, H. H. Detection of methicillinresistant Staphylococcus aureus and simultaneous confirmation by automated nucleic acid extraction and realtime PCR. Journal of Clinical Microbiology, v. 40, n. 7, p. 2392-2397, 2002. doi: 10.1128/JCM.40.7.2392-2397.2002.

HAN, T. X.; WANG, E. T.; HAN, L. L.; CHEN, W. F.; SUI, X. H.; CHEN, W. X. Molecular diversity and phylogeny of rhizobia associated with wild legumes native to Xinjiang, China. Systematic and Applied Microbiology, v. 31, n. 4, p. 287-301, 2008. doi: 10.1016/j.syapm.2008.04.004.

HANSELMAN, B. A.; KRUTH, S. A.; ROUSSEAU, J.; LOW, D. E.; WILLEY, B. M.; MCGEER, A.; WEESE, J. S. Methicillin-resistant Staphylococcus aureus colonization in veterinary personnel. Emerging Infectious Disease, v. 12, n. 12, p. 1933-1938, 2006.

HOPPE-SEYLER, T. S.; JAEGER, B.; BOCKELMANN, W.; NOORDMAN, W. H.; GEIS, A.; HELLER, K. J. Molecular identification and differentiation of Staphylococcus species and strains of cheese origin. Systematic and 
Applied Microbiology, v. 27, n. 2, p. 211-218, 2004. doi: $10.1078 / 072320204322881835$.

INGIANNI, A.; PETRUZZELLI, S.; MORANDOTTI, G.; POMPEI, R. Genotypic differentiation of Gardnerella vaginalis by amplified ribosomal DNA restriction analysis (ARDRA). FEMS Immunology and Medical Microbiology, v. 18, n. 1, p. 61-66, 1997. doi: 10.1111/j.1574695X.1997.tb01028.x.

JENG, R. S.; SVIRCEV, A. M.; MYERS, A. L.; BELIAEVA, L.; HUNTER, D. M.; HUBBES, M. The use of $16 \mathrm{~S}$ and 16S-23S rDNA to easily detect and differentiate common Gram-negative orchard epiphytes. Journal of Microbiological Methods, v. 44, n. 1, p. 69-77, 2001.

KEARNS, A. M.; SEIDERS, R. P.; WHEELER, J.; FREEMAN, R.; STEWARD, M. Rapid detection of methicillin-resistant Staphylococci by multiplex PCR. Journal of Hospital Infection, v. 43, n. 1, p. 33-37, 2001. doi: 10.1053/jhin.1999.0631.

KHICHAR, V.; KATARIA, A. K.; SHARMA, R. Characterization of Staphylococcus aureus of cattle mastitis origin for two virulence-associated genes (coa and spa). Comparative Clinical Pathology, v. 23, n. 3, p. 603-611, 2012. doi: 10.1007/s00580-012-1657-5.

KUEHNERT, M. J.; KRUSZON-MORAN, D.; HILL, H. A.; MCQUILLAN, G.; MCALLISTER, S.; FORSHEIM, G.; MCDOUGAL, L. K.; CHAITRAM, J.; JENSEN, B.; FRIDKIN, S. K.; KILLGORE, G.; TENOVER, F. C. Prevalence of Staphylococcus aureus Nasal Colonization in the United States, 2001-2002. The Journal of Infectious Diseases, v. 193, n. 2, p. 172-179, 2006.

KUMAR, V.; RANA, R.; MEHRA, S.; ROUT, P. K. Isolation and characterization of mycoplasma mycoides subspecies capri from milk of natural goat mastitis cases. ISRN Veterinary Sciences, v. 2013, 2013. doi: $10.1155 / 2013 / 593029$.

LEE, J. H. Methicillin (oxacillin)-resistant Staphylococcus aureus strains isolated from major foods animals and their potential transmission to humans. Applied and Environmental Microbiology, v. 69, n. 11, p. 6489-6494, 2003. doi: 10.1128/AEM.69.11.6489-6494.2003.
LOEFFLER, A.; BOAG, A. K.; SUNG, J.; LINDSAY, J. A.; GUARDABASSI, L.; DALSGAARD, A.; SMITH, H.; STEVENS, B.; LLOYD, D. H. Prevalence of methicillinresistant Staphylococcus aureus among staff and pets in the small animal in referral hospital in the UK. The Journal of Antimicrobial Chemotherapy, v. 56, n. 4, p. 692-697, 2005. doi: 10.1093/jac/dki312.

MATTHEWS, K. R.; ROBERSON, J.; GILLESPIE, B. E.; LUTHER, D. A.; OLIVER, S. P. Identification and differentiation of coagulase-negative Staphylococcus aureus by Polymerase Chain Reaction. Journal of Food Protection, v. 60, n. 6, p. 686-688, 1997. doi: 10.4315/0362028X-60.6.686.

MENEGOTTO, F. R.; PICOLI, S. U. Staphylococcus aureus oxacilina resistente (MRSA): incidência de cepas adquiridas na comunidade (CA-MRSA) e importância da pesquisa e descolonização em hospital. Revista Brasileira de Análises Clínicas, v. 39, n. 2, p. 147-150, 2007.

NEMA, V.; AGRAWAL, R.; KAMBOJ, D. V.; GOEL, A. K.; SINGH, L. Isolation and characterization of heat resistant enterotoxigenic Staphylococcus aureus from a food poisoning outbreak in Indian subcontinent. International Journal of Food Microbiology, v. 117, n. 1, p. 29-35, 2007. doi: 10.1016/j.ijfoodmicro.2007.011.015 .

O'MAHONY, R. O.; ABBOTT, Y.; LEONARD, F. C.; MARKEY, B. K.; QUINN, P. J.; POLLOCK, P. J.; FANNING, S.; ROSSNEY, A. S. Methicillin-resistant Staphylococcus aureus (MRSA) isolated from animals and veterinary personnel in Ireland. Veterinary Microbiology, v. 109, n. 3-4, p. 285-296, 2005. doi: 10.1016/j.vetmic.2005.06.003.

OMAR, N. Y.; ALI, H. A.; HARFOUSH, R. A.; EL KHAYAT, E. H. Molecular typing of methicillin resistant Staphylococcus aureus clinical isolates on the basis of protein A and coagulase gene polymorphisms. International Journal of Microbiology, v. 2014, p. 1-11, 2014. doi: $10.1155 / 2014 / 650328$.

OTE, I.; TAMINIAU, B.; DUPREZ, J. N.; DIZIER, I.; MAINIL, J. G. Genotypic characterization by polymerase chain reaction of Staphylococcus aureus isolates associated with bovine mastitis. Veterinary Microbiology, v. 153, n. 3-4, p. 285-292, 2011. doi: 10.1016/j.vetmic.2011.05.042.

Braz. J. Vet. Res. Anim. Sci., São Paulo, v. 54, n. 2, p. 117-128, 2017 
ÖZTÜRK, M.; METERELLIYÖZ, M. Practical identification of human originated Lactobacillus species by amplified ribosomal DNA restriction analysis (ARDRA) for probiotic use. Molecular Biology Reports, v. 42, n. 8, p. 1323-1332, 2015. doi: 10.1007/s11033-015-3877-7.

PANTOSTI, A. Methicillin-Resistant Staphylococcus aureus associated with animals and its relevance to human health. Frontiers in Microbiology, v. 3, 2012. doi: 10.3389/ fmicb.2012.00127.

PEREIRA, V. C.; MARTINS, A.; DE SOUZA RUGOLO, L. M.; CUNHA, M. L. R. S. Detection of oxacillin resistance in Staphylococcus aureus isolated from the neonatal and pediatric units of a Brazilian teaching hospital. Clinical Medicine: Pediatrics, v. 3, p. 23-31, 2009.

PÉREZ-ROTH, E.; CLAVERIE-MARTÍN, F.; VILLAR, J.; MÉNDEZ-ALVARES, S. Multiplex PCR for simultaneous identification of Staphylococcus aureus and detection of methicillin and mupirocin resistance. Journal of Clinical Microbiology, v. 39, n. 11, p. 4037-4041, 2001. doi: 10.1128/ JCM.39.11.4037-4041.2001.

PERILLO, J.; CECCARELLI, D.; SPAGNOLETTI, M.; LOLLAI, M.; CAPPUCCINELLI, P.; COLOMBO, M. M. Molecular characterization of enterotoxigenic and borderline oxacillin resistant staphylococcal strains from ovine milk. Food Microbiology, v. 32, n. 2, p. 265-273, 2012. doi: 10.1016/j.fm.2012.06.009.

RABELO, M. A.; NETO, A. M. B.; SILVA, E. C. B.; OLIVEIRA, W. L. M.; MELO, F. L.; LOPES, A. C. S.; LEAL, N. C.; MACIEL, M. A. V. Phenotypic methods for determination of methicillin resistance in Staphylococcus spp. from health care workers. Jornal Brasileiro de Patologia e Medicina Laboratorial, v. 49, n. 2, p. 91-96, 2013. doi: 10.1590/S1676-24442013000200003.

RADWAN, I. A. H.; SHEHATA, A. A. E.; ABDEL-GHANI, A. E.; ABDUllah, M. M.; ABDRABOH, A. A. M. Phenotypic and genotypic diversity of Staphylococcus aureus isolated from livestock and human. Global Veterinary, v. 14, n. 2, p. 274-281, 2015. doi: 10.5829/idosi.gv.2015.14.02.91155.

ROTH, A.; REISCHL, U.; STREUBEL, A.; NAUMANN, L.; KROPPENSTEDT, R. M.; HABICHT, M.; FISCHER, M.;
MAUCH, H. Novel diagnostic algorithm for identification of mycobacteria using genus-specific amplification of the 16S-23S rRNA gene spacer and restriction endonucleases. Journal of Clinical Microbiology, v. 38, n. 3, p. 10941104, 2000.

SÁ, M.E.P.; CUNHA, M.L. R.S.; ELIAS, A. O.; VICTÓRIA, C.; LANGONI, H. Importância do Staphylococcus aureus nas mastites subclínicas: pesquisa de enterotoxinas e toxina do choque tóxico e a relação com a contagem de células somáticas. Brazilian Journal of Veterinary Research and Animal Science, v. 41, n. 5, p. 320-326, 2004. doi: 10.1590/ S1413-95962004000500005.

SAKWINSKA, O.; GIDDEY, M.; MOREILLON, M.; MORISSET, D.; WALDVOGEL, A.; MOREILLON, P. Staphylococcus aureus Host Range and Human-Bovine Host Shift. Applied and Environmental Microbiology, v. 77, n. 17, p. 5908-5915, 2001. doi: 10.1128/AEM.00238-11.

SANDES, S. H.; ALVIN, L. B.; SILVA, B. C.; ZANIRATI, D. F.; JUNG, L. R.; NICOLI, J. R.; NEUMANN, E.; NUNES, A. C. Lactobacillus species identification by amplified ribosomal 16S-23S rRNA restriction fragment length polymorphism analysis. Beneficial Microbes, v. 5, n. 4, p. 471-481, 2014. doi: 10.3920/BM2013.0092.

SANJIV, K.; KATARIA, A. K.; SHARMA, R.; SINGH, G. Epidemiological typing of Staphylococcus aureus by DNA restriction fragment length polymorphism of coa gene. Veterinarski Arhiv, v. 78, n. 1, p. 31-38, 2008. Available from: <https://goo.gl/J7GSiY>. Viewed: 19 June 2017.

SANTHOSH, D. V.; SHOBHA, K. L.; BAIRY, I.; RAO, G.; ANAND, K. M.; D'SOUZA, J. Nasal screening and survey of pre-clinical students from Malaysia for nasal carriage of coagulase positive MRSA and rate of nasal colonization with Staphylococcus species. Journal of Clinical and Diagnostic Research, v. 6, n. 6, p. 494-499, 2007. Available from: <https://goo.gl/15XYB7>. Viewed: 19 June 2017.

SEARS, P. M.; MCCARTHY, K. K. Management and treatment of staphylococcal mastitis. Veterinary Clinics of North America: Food Animal Practice, v. 19, n. 1, p. 171-185, 2003. 
SON, J. S.; LEE, S. J.; JUN, S. Y.; YOON, S. J.; KANG, S. H.; PAIK, H. R.; KANG, J. O.; CHOI, Y. J. Antibacterial and biofilm removal activity of a podoviridae Staphylococcus aureus bacteriophage SAP-2 and a derived recombinant cell-wall-degrading enzyme. Applied Microbiology and Biotechnology, v. 86, n. 5, p. 1439-1449, 2010. doi: 10.1007/ s00253-009-2386-9.

SOON, T. H.; FONG, N. Y.; JAMAL, F. Antibiotic susceptibility of community-acquired Staphylococcus aureus.

Medical Journal of Malaysia, v. 41, n. 1, p. 24-29, 1986.

VANEECHOUTTE, M.; DIJKSHOORN, L.; TJERNBERG, I.; ELAICHOUNI, A.; DE VOS, P.; CLAEYS, G.; VERSCHRAEGEN, G. Identification of Acinetobacter genomic species by amplified ribosomal DNA restriction analysis. Journal of Clinical Microbiology, v. 33, n. 1, p. 11-15, 1995.

VON EIFF, C.; BECKER, K.; MACHKA, K.; STAMMER, H.; PETERS, G. Nasal carriage as a source of Staphylococcus aureus bacteremia. The New England Journal of Medicine, $\mathrm{v}$. 344, n. 1, p. 11-16, 2001 doi: 10.1056/NEJM200101043440102.

WEESE, J. S.; CALDWELL, F.; WILLEY, B. M.; KREISWIRTH, B. N.; MCGREER, A.; ROUSSEAU, J.; LOW, D. E. An outbreak of methicillin-resistant Staphylococcus aureus skin infections resulting from horse to human transmission in a veterinary hospital. Veterinary Microbiology, v. 114, n. 1-2, p. 160-164, 2006. doi: 10.1016/j.vetmic.2005.11.054.
WILSON, D. J.; GONZALES, R. N.; DAS, H. H. Bovine mastitis pathogens in New York and Pennsylvania: prevalence and effects on somatic cell count and milk production. Journal of Dairy Science, v. 80, n. 10, p. 25922598, 1997. doi: 10.3168/jds.S0022-0302(97)76215-5.

WOESE, C. R.; MANILOFF, J.; ZABLEN, L. B. Phylogenetic analysis of the mycoplasmas. Proceedings of the National Academy of Sciences USA, v. 77, n. 1, p. 494-498, 1980.

WULF, M.; VAN NES, A.; EIKELENBOOM-BOSKAMP, A.; VRIES, J.; MELCHERS, W.; KLAASSEN, C.; VOSS, A. Methicillin-resistant Staphylococcus aureus in veterinary doctors and students, the Netherlands. Emerging Infectious Diseases, v. 12, n. 12, p. 1939-1941, 2006. doi: 10.3201/eid1212.060355.

YOUNG, J. P.; DOWNER, H. L.; EARDLY, B. D. Phylogeny of the phototrophic Rhizobium strain BTAil by polymerase chain reaction-based sequencing of a $16 \mathrm{~S}$ rRNA gene segment. Journal of Applied Bacteriology, v. 173, n. 7, p. 2271-2277, 1991.

ZAVADINACK, M. N.; HERREIRO, F.; BANDEIRA, C. O. P.; ITO, Y.; CIORLIN, E. M.; SAQUETI, E. E.; ANSILEIRO, I. J.; GONÇALVES, L.; SIQUEIRA, V. L. Staphylococcus aureus: incidência e resistência antimicrobiana em abscessos cutâneos de origem comunitária. Acta Scientiarum, v. 23, n. 3, p. 709-712, 2001. doi: 10.4025/ actascihealthsci.v23i0.2922. 